\title{
PENGARUH PENGGUNAAN ALAT PERAGA AEM (ALGEBRAIC EXPERIENCE MATERIALS) TERHADAP KETERAMPILAN BERPIKIR KREATIF SISWA POKOK BAHASAN OPERASI BENTUK ALJABAR
}

\author{
Siti Jamilah, Reza Oktiana Akbar \\ Tadris Matematika, IAIN Syekh Nurjati Cirebon \\ Jalan perjuangan Bypass Sunyaragi
}

\begin{abstract}
Mathematicts learning process ussually takes place with the lecture method. So that students just listen, not many ideas put forward, students feel bored, especially math lessons they find difficult. In mathematical operations form the subject of algebra are abstract elements, they have difficulty understanding abstract concepts. One effort to help students understand the concept of algebra by using props AEM (Algebraic Experience Materials). The purpose of this study to determine the students 'response to the use of props AEM (Algebraic Experience Materials), to determine students' creative thinking skills in the subject of mathematics learning operations in the algebra of MTs AlHidayah Ciawijapura. In addition, to determine the effect of the use of props AEM (Algebraic Experience Materials) to creative thinking skills of students on the subject of operations in the algebra of MTs Al Hidayah Ciawijapura. Based on the results of the study, students' response to the use of props AEM (Algebraic Experience Materials) in mathematics including a very strong category with an average of $82.23 \%$. Creative thinking skills of students in mathematics learning test average of $75.21 \%$, the value of good category. While the results of the use of the analysis of hypothesis testing showed t_hitung> t_tabel or 2.977> 2.042. This means that the use of props AEM (Algebraic Experience Materials) to creative thinking skills of students there is the influence of $22.29 \%$ and the remaining $77.71 \%$ influenced by other factors not examined.
\end{abstract}

Kata Kunci : AEM (Algebraic Experience Materials)

\section{PENDAHULUAN}

Matematika sering dianggap sebagai ilmu yang hanya menekankan pada kemampuan berpikir logis dengan penyelesaian tunggal dan pasti. Hal ini yang menyebabkan matematika sering dianggap sebagai mata pelajaran yang susah. Anggapan matematika sebagai mata pelajaran yang dianggap susah harus disiasati oleh guru mata pelajaran matematika agar siswa senang dan tertarik untuk belajar matematika. Metode dan media pembelajaran yang bervariasi dapat membantu guru dalam mensiasati pembelajaran agar mudah diterima dan dapat mengembangkan kreativitas siswa. Berpikir kreatif menurut Lawson (1980) dimaknai sebagi suatu proses kreatif, yaitu merasakan adanya kesulitan, masalah, kesenjangan informasi, adanya unsur yang hilang, dan ketidakharmonisan, mendefinisikan masalah secara jelas, membuat dugaan-dugaan atau merumuskan hipotesis tentang kekurangan-kekurangan, menguji dugaan-dugaan tersebut dan kemungkinan perbaikannya, pengujian kembali atau bahkan mendefinisikan ulang masalah, dan akhirnya mengkomunikasikan hasilnya.
Strategi kognitif merupakan suatu pendekatan belajar yang menekankan perkembangan proses dan keterampilan berpikir sebagai alat untuk meningkatkan pembelajaran yang bertujuan agar seluruh pembelajar menjadi lebih strategis, percaya diri, fleksibel, dan produktif dalam usaha belajarnya. Strategi kognitif sering disebut strategi berpikir atau strategi belajar, karena strategi ini sering digunakan dalam belajar yang melibatkan pemikiran (Nurhayati, 2010 :25). Menurut teori kognitif bahwa untuk membantu anak mencapai taraf berpikir abstrak harus banyak diberikan pengalaman-pengalaman dan untuk memperbanyak pengalaman-pengalaman anak, harus dilakukan dengan berbagai alat peragaan.

Salah satu faktor untuk membangkitkan belajar anak adalah dengan penggunaan alat peraga. Hal ini dapat dilakukan dengan cara langsung, yaitu memperlihatkan bendanya sendiri, mengadakan percobaan-percobaan yang dapat diamati peserta didik, misalnya pendidik membawa alat-alat atau benda ke dalam kelas. Secara tidak langsung yaitu dengan menunjukkan benda tiruan misalnya gambar, foto, film, dsb. Peranan alat peraga 
dalam pembelajaran matematika sangat penting, karena alat peraga disamping membantu guru untuk menjelaskan konsepkonsep yang sedang dipelajari, alat peraga juga membantu siswa agar berpikir kreatif karena dengan alat peraga siswa mampu mengembangkan konsep-konsep yang sudah ada dengan mempraktikan langsung atau mengaplikasikan teori dalam kondisi riil. Sehingga dalam menentukan masalah atau mengerjakan soal siswa mampu mengerjakannya dengan cara yang bervariatif (Mustaqim, 2010).

Konsep - konsep matematika yang dipelajari banyak, diantaranya yang melibatkan penggunaan alat peraga, dimana melalui penggunaan alat peraga akan dapat membantu siswa dalam memahami materi ajar yang mereka pelajari. Namun, dapat dimaklumi sebab tidak semua alat peraga dapat dibuat dengan biaya yang murah apalagi banyak terdapat sekolah memiliki permasalahan dengan pembiayaan. Terdapat beberapa guru yang menganggap penggunaan dari alat peraga tidak akan membantu siswa dalam memahami materi ajar, tetapi hanya akan menghabiskan jam pelajaran saja. Padahal penggunaan dari alat peraga akan dapat memberikan siswa pengalaman yang nyata dan juga akan memberikan motivasi yang lebih kuat untuk mempelajari matematika dikarenakan mereka mengetahui kegunaan dari materi ajar yang mereka pelajari. Kemampuan mengoperasikan bentuk aljabar yang baik tidak dapat dipisahkan dari pemahaman yang baik dari konsep-konsep yang terkait misalnya pemahaman tentang lambang aljabar berupa suku, faktor, variabel, konstanta, koefisien, dan

lainnya. Dengan pemahaman yang baik terhadap konsep-konsep itu, diharapkan kompetensi menyelesaikan operasi bentuk aljabar akan dikuasai dengan baik.

\section{KAJIAN TEORI}

Pembelajaran adalah suatu proses yang dilakukan oleh individu untuk memperoleh suatu perubahan prilaku yang baru secara keseluruhan, sebagai hasil dari pengalaman individu itu sendiri dalam interaksi dengan lingkungannya (Surya, 2004: 7). Menurut Winkel (Siregar \& Nara, 2010: 12) pembelajaran adalah seperangkat tindakan yang dirancang untuk mendukung proses belajar siswa, dengan memperhitungkan kejadian- kejadian ekstrim yang berperanan terhadap rangkaian kejadian-kejadian intern yang berlangsung dialami siswa.
Pembelajaran adalah suatu kombinasi yang tersusun meliputi unsur-unsur manusiawi, material, fasilitas, perlengkapan dan prosedur yang saling mempengaruhi mencapai tujuan pembelajaran (Hamalik, 1995: 57).

Dari segi ethimology, alat peraga merupakan alat yang mempergunakan suatu konsep atau prinsip. Makna "memperagakan" adalah menjadikannya jelas secara visual, atau menjadikannya konkrit (dapat disentuh), atau menjadikannya bekerja pada suatu konteks.

Menurut Elly Estiningsih (1994) dalam Pujiati (2004:3) disebutkan bahwa alat peraga merupakan media pengajaran yang mengandung atau membawakan ciri-ciri dari konsep yang dipelajari. Alat peraga matematika adalah seperangkat benda konkrit yang dirancang, dibuat, dihimpun atau disusun secara sengaja yang digunakan untuk membantu menanamkan atau mengembangkan konsep-konsep atau prinsip-prinsip dalam matematika (Djoko Iswadi dalam Pujiati, 2004:3).

Nana Sudjana (1998 : 99 - 100), menyatakan bahwa ada 6 fungsi pokok dari alat peraga dalam proses belajar mengajar, keenam fungsi tersebut adalah :

1. Penggunaan alat peraga dalam belajar mengajar bukan merupakan fungsi tambahan tetapi mempunyai fungsi tersendiri sebagai alat bantu untuk mewujudkan situasi belajar mengajar yang efektif.

2. Penggunaan alat peraga merupakan bagian yang integral dari keseluruhan situasi mengajar. Ini berarti bahwa alat peraga merupakan salah satu unsuryang harus dikembangkan oleh guru.

3. Alat peraga dalam pengajaran penggunaannya integral dengan tujuan dan isi pelajaran.

Fungsi ini mengandung pengertian bahwa penggunaan alat peraga harus melihat kepada tujuan dan bahan pelajaran.

1. Penggunaan alat peraga dalam pembelajaran bukan semata-mata alat hiburan, dalam artian digunakan hanya sekedar melengkapi proses belajar supaya lebih menarik perhatian siswa.

2. Penggunaan alat peraga dalam pembelajaran lebih diutamakan untuk mempercepat proses belajar mengajar dan membantu siswa dalam menangkap pengertian yang diberikan guru.

3. Penggunaan alat peraga dalam pembelajaran digunakan untuk 
mempertinggi mutu belajar mengajar, dengan kata lain menggunakan alat peraga hasil belajar yang dicapai akan tahan lama diingat oleh siswa sehingga pelajaran mempunyai nilai tinggi.

Menurut Azhar (2009 : 73), ada beberapa kriteria yang harus diperhatikan dalam memilih alat peraga dalam proses belajar mengajar yaitu :

1. Sesuai dengan tujuan belajar yang ingin dicapai.

2. Tempat yang mendukung isi pelajaran yang sifatnya fakta, konsep, prinsip atau generalisasi.

3. Praktis, luwes dan bertahan.

4. Guru terampil dalam menggunakannya.

5. Mengelompokkan sasaran, maksdunya alat peraga yang efektif pada kelompok besar belum tentu efektifnya jika digunakan pada kelompok kecil.

6. Alat peraga harus memenuhi persyaratan mutu dan teknis tertentu.

Alat peraga AEM (Algebraic Experience Materials) atau istilah lainnya blok aljabar diperkenalkan dan dikembangkan di Victoria pada tahun 1970an oleh Charles Lovitt, Colin Mariott, dan Ken Swan. Alat peraga ini merupakan model geometri yang digunakan untuk mengkonkritkan pengertian variabel dan konstanta dalam aljabar yang merupakan konsep abstrak. Alat peraga Algebraic Experience Materials (AEM) terdiri dari blok-blok yang berbentuk bangun geometri seperti: persegi dan persegi panjang serta mengacu pada konsep panjang, lebar, dan luas (Teguh Membara, 2012).

Tujuan dari penggunaan alat peraga AEM (Algebraic Experience Materials) ini adalah memberikan kesempatan bagi siswa untuk mengaplikasikan pengetahuan mereka tentang penjumlahan bentuk aljabar, penguragan bentuk aljabar, perkalian suku satu dengan suku dua, dan perkalian suku dua dengan suku dua bentuk aljabar. Dengan menggunakan alat peraga AEM (Algebraic Experience Materials) siswa lebih mudah memahami konsep aljabar yang diajarkan, sehingga keterampilan berpikir kreatif siswa akan meningkat dengan mengerjakan soal bentuk open ended (Teguh Membara, 2012).

Menurut Nurhayati (2010 : 27), keterampilan merupakan kecakapan melakukan suatu tugas tertentu yang diperoleh dengan cara berlatih terus menerus, karena keterampilan tidak serta merta datang sendiri secara otomatis dan kebetulan, melainkan secara sengaja diprogram melalui latihan terus menerus. Robert (Wahidin, 2004 ; Nurhayati, 2010: 30) berpendapat, berpikir merupakan proses mental melalui membayangkan, memanipulasi dan menggambarkan idea abstrak berupa anggapan, pendapat, tanggapan terhadap sesuatu dalam pikiran ( $m i n d) \quad$ seseorang. Berpikir adalah merupakan suatu proses kognitif dalam tingkat yang lebih tinggi. Dalam berpikir, individu akan menggunakan berbagai informasi yang dimilikinya untuk memecahkan masalah yang dihadapinya (Siregar \& Nara, 2004: 11).

Berpikir kreatif dapat dikembangkan melalui latihan yang bersifat kognitif, terutama latihan berpikir, dan latihan non kognitif seperti sikap berani mencoba sesuatu yang baru, penambahan motivasi untuk berkreasi, dan sifap berani menanggung resiko, serta pengembangan kepercayaan diri dan harga diri. (Davis \& Bull, 1978; Lott, 1978; Sobel, 1980; Munandar, 1985; dalam Nurhayati, 2010).

\section{METODOLOGI PENELITIAN}

Penelitian ini akan dilaksanakan di MTs AlHidayah Ciawijapura Kecamatan Susukanlebak Kabupaten Cirebon. Sekolah ini terletak di Jl.Raya Ciawijapura Desa Ciawijapura Kecamatan Susukanlebak Kabupaten Cirebon Kode Pos 45185, Telepon (0231) 8639329. Dengan tenaga pengajar berjumlah 18 guru dan 5 orang tenaga admin. Sedangkan siswanya berjumlah 267 siswa. Alasan pemilihan lokasi penelitian ini adalah karena penelitian yang sejenis belum pernah dilaksanakan di sekolah tersebut. Dalam penelitian ini, penulis mengambil sampel siswa kelas VIII C MTs. AlHidayah Ciawijapura yang berjumlah 33 siswa.

Metode yang digunakan dalam penelitian ini adalah menggunakan metode penelitian kuantitatif. Metode penelitian kuantitatif adalah suatu cara untuk memperoleh ilmu pengetahuan atau memecahkan masalah yang dihadapi dan dilakukan secara hati-hati dan sistematis, dimana data-data yang dikumpulkan berupa rangkaian atau kumpulan angkaangka (Nasehuddien, 2011: 48).

Berdasarkan variabel-variabel yang digunakan, maka desain yang dipakai dalam judul skripsi ini disesuaikan dengan metode penelitian yang digunakan, yaitu one shot case study. 
Treatment

Post test

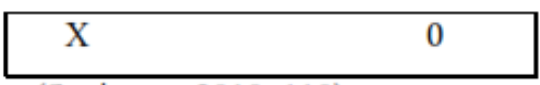

(Sugiyono, 2010: 110)

\section{Keterangan :}

$\mathrm{X}=$ treatment yang diberikan (variabel indepenc

0 = Observasi (variabel dependen)

Penulis melakukan analisis angket respon siswa terhadap penggunaan alat peraga AEM (Algebraic Experience Materials) dengan membagi lima kriteria penilaian, yaitu sangat setuju, setuju, netral, tidak setuju, dan sangat tidak setuju. Untuk skor setiap pernyataan dapat dilihat dari tabel berikut: Penskoran Angket

\begin{tabular}{|c|c|c|}
\hline \multirow{2}{*}{ Kriteria } & \multicolumn{2}{|c|}{ Angket } \\
\cline { 2 - 3 } & Pernyataan Positif (+) & Pernyataan Negatif (-) \\
\cline { 2 - 3 } & Bobot Nilai & Bobot Nilai \\
\hline Sangat Setuju & 5 & 1 \\
\hline Setuju & 4 & 2 \\
\hline Netral & 3 & 3 \\
\hline Tidak Setuju & 2 & 4 \\
\hline Sangat Tidak Setuju & 1 & 5 \\
\hline
\end{tabular}

Untuk menghitung persentase setiap butir pernyataan angket yaitu : skor yang diperoleh dibagi skor ideal/skor maksimal kemudian dikali 100\% (Riduwan, 2012: 89). Dimisalkan $P$ adalah presentasi jawaban, $f$ adalah frekuensi jawaban yang diperoleh, maka dapat dirumuskan sebagai berikut:

$$
P=\frac{f}{\text { skor.maks }} \times 100 \%
$$

Adapaun kriteria interpretasi skor angket dapat dilihat dalam tabel beril Tabel 3.13

\begin{tabular}{|c|c|}
\multicolumn{2}{|c|}{ Kriteria Interpretasi Skor Angket } \\
\hline Angka & Kriteria \\
\hline $0 \% \leq \mathrm{P} \leq 20 \%$ & Sangat Lemah \\
\hline $20 \%<\mathrm{P} \leq 40 \%$ & Lemah \\
\hline $40 \%<\mathrm{P} \leq 60 \%$ & Cukup \\
\hline $60 \%<\mathrm{P} \leq 80 \%$ & Kuat \\
\hline $80 \%<\mathrm{P} \leq 100 \%$ & Sangat Kuat \\
\hline
\end{tabular}

Skala penilaian tes keterampilan berpikir kreatif menggunakan skor dengan interval 0-100. Adapun kriteria skor yang diperoleh dapat dilihat pada tabel berikut:

\begin{tabular}{|c|c|}
\multicolumn{2}{|c}{ Kategori Perolehan Skor Tes } \\
\hline Nilai & Kriteria \\
\hline $\mathrm{S} \leq 40$ & Sangat Kurang \\
\hline $40<\mathrm{S} \leq 55$ & Kurang Baik \\
\hline $55<\mathrm{S} \leq 70$ & Cukup \\
\hline $70<\mathrm{S} \leq 85$ & Baik \\
\hline $85<\mathrm{S} \leq 100$ & Sangat Baik \\
\hline
\end{tabular}

Adapun analisis presentasi jawaban dihitung menggunakan rumus sebagai berikut:

$$
P=\frac{f}{\text { skor.maks }} \times 100 \%
$$

Kriteria Interpretasi Skor Tes

\begin{tabular}{|c|c|}
\hline Angka & Kriteria \\
\hline $0 \% \leq \mathrm{P} \leq 20 \%$ & Sangat Lemah \\
\hline $20 \%<\mathrm{P} \leq 40 \%$ & Lemah \\
\hline $40 \%<\mathrm{P} \leq 60 \%$ & Cukup \\
\hline $60 \%<\mathrm{P} \leq 80 \%$ & Kuat \\
\hline $80 \%<\mathrm{P} \leq 100 \%$ & Sangat Kuat \\
\hline
\end{tabular}

(Riduwan, 2012: 89)

\section{HASIL PENELITIAN}

Deskripsi data dalam penelitian ini diambil melalui penyebaran skala sikap (angket) dan tes yang diberikan kepada siswa kelas VIII C MTs Al-Hidayah Ciawijapura yang berjumlah 33 siswa. Angket digunakan untuk mengetahui respon siswa terhadap penggunaan alat peraga AEM (Algebraic Eksperience Materials) dalam pembelajaran operasi bentuk aljabar, angket yang digunakan berupa pernyataan yang terdiri dari 20 item.

\begin{tabular}{|l|l|l|l|l|l|l|}
\hline & N & Min & Max & Mean & $\begin{array}{l}\text { Std. } \\
\text { Dev }\end{array}$ & Var \\
\hline $\begin{array}{l}\text { Penggunaan } \\
\text { Alat Peraga } \\
\text { AEM }\end{array}$ & 33 & 72 & 97 & 82,73 & 7,090 & 50,26 \\
\hline
\end{tabular}

Dari tabel di atas diketahui output deskriptif statistik yang menunjukkan skor minimal yang diperoleh siswa terhadap respon penggunaan alat peraga AEM (Algebraic Eksperience Materials) adalah 72 dengan kategori kuat, sedangkan skor maksimal yang diperoleh siswa adalah 97 dengan kategori sangat kuat. Perolehan rata-rata respon siswa terhadap penggunaan alat peraga AEM (Algebraic Eksperience Materials) adalah 82,73 dengan interpretasi $82,73 \%$, sehingga nilai tersebut dapat dikategorikan bahwa respon siswa terhadap penggunaan alat peraga AEM (Algebraic Eksperience Materials) sangat kuat. 
Sedangkan standar deviasi yang diperoleh adalah 7,090 dan nilai variansnya adalah 50,267 .

Berdasarkan hasil yang diperoleh data dari indikator pertama peran alat peraga AEM (Algebraic Eksperience Materials) dalam pembelajaran matematika dengan nomor item 1,5, dan 7. Persentase rata-rata perolehan skor sebesar $86,67 \%$ dengan kategori sangat kuat. Karena alat peraga AEM (Algebraic Eksperience Materials) dapat memperjelas penyampaian materi aljabar dan dapat menggambarkan unsur-unsur yang abstrak menjadi konkrit.

Hasil perhitungan angket respon diketahui persentase rata-rata indikator ketertarikan siswa terhadap alat peraga AEM (Algebraic Eksperience Materials) sebesar 85,66\% dengan kategori sangat kuat. Siswa merasa senang karena mereka dapat melihat langsung unsur-unsur aljabar yang digambarkan dengan alat peraga AEM (Algebraic Eksperience Materials).

Hasil perhitungan persentase rata-rata dari indikator minat siswa terhadap alat peraga AEM (Algebraic Eksperience Materials) dalam pembelajaran matematika adalah sebesar $84,09 \%$. Hal ini menunjukkan bahwa interpretasi angket pada indikator minat siswa terhadap alat peraga AEM (Algebraic Eksperience Materials).

Persentase rata-rata dari indikator pemahaman dan keterampilan berpikir kreatif siswa ketika belajar menggunakan alat peraga AEM (Algebraic Eksperience Materials) menunjukkan bahwa kemahaman dan keterampilan berpikir kreatif siswa sangat kuat dengan interpretasi sebesar $84,24 \%$. Sebagian besar siswa sangat setuju bahwa konsep aljabar lebih mudah dipahami dengan menggunakan alat peraga AEM.

Berdasarkan tabel tersebut, persentase ratarata pada indikator efektifitas dan efisiensi penggunaan alat peraga AEM (Algebraic Eksperience Materials) adalah sebesar 2,73\% dan termasuk kategori kuat.

Keterampilan berpikiir kreatif

\begin{tabular}{|l|l|l|l|l|l|l|}
\hline & N & Min & Max & Mean & $\begin{array}{l}\text { Std } \\
\text { Dev }\end{array}$ & Var \\
\hline $\begin{array}{l}\text { Ket } \\
\text { Brpikir } \\
\text { kreatif }\end{array}$ & 33 & 58 & 90 & 73,42 & 5,990 & 35,877 \\
\hline
\end{tabular}

Skor minimal yang diperoleh siswa dalam keterampilan berpikir kreatif adalah 58, sedangkan skor maksimal yang diperoleh siswa adalah 90. Perolehan rata-rata keterampilan berpikir kreatif siswa adalah
73,42 dengan interpretasi $73,42 \%$, sehingga nilai tersebut dapat dikategorikan bahwa keterampilan berpikir kreatif siswa kuat. Sedangkan standar deviasi yang diperoleh adalah 5,990 dan nilai variansnya adalah 35,877 .

Berdasarkan hasil analisis data diperoleh data dari indikator pertama yaitu siswa mampu memberikan jawaban yang bervariasi untuk setiap soal. Pertanyaan nomor 2 ini rata-ratanya adalah 67,58\% dengan kategori kuat. Sebagian besar siswa mampu memberikan jawaban yang bervariasi.

Berdasarkan analisis respon diperoleh data dari indikator kedua yaitu siswa mampu menjawab setiap soal dengan tepat tetapi tidak terpaku pada satu cara. Pertanyaan nomor 4 ini rata-ratanya adalah 76,97\% dengan kategori kuat. Sebagian siswa mampu menjawab soal dengan tepat.

Berdasarkan hasil diperoleh data dari indikator ketiga yaitu siswa mampu memberikan jawaban menurut pandangannya sendiri. Dari kedua pertanyaan di atas diperoleh rata-ratanya sebesar 66,29\% dengan kategori kuat.

Berdasarkan hasil diperoleh data dari indikator terakhir yaitu siswa mampu mengembangkan atau memperkaya gagasan jawaban suatu soal. Persentase rata-ratanya sebesar 90,00\% dengan kategori sangat kuat.

Tes normality

\begin{tabular}{|c|c|c|c|}
\hline \multirow{2}{*}{ Var } & \multicolumn{3}{|c|}{ Kolmogorov Smirnov } \\
\cline { 2 - 4 } & Statistic & Df & Sig \\
\hline Var 1 & 0,132 & 33 & 0,157 \\
\hline Var 2 & 0,165 & 33 & 0,024 \\
\hline
\end{tabular}

Dapat dilihat pada tabel di atas, dengan tingkat kepercayaan a $=0,05$ diperoleh nilai signifikansinya pada kolom Shapiro Wilk adalah 0,130 dan 0,074. Karena nilai signifikansinnya lebih besar dari 0,05 maka data berdistribusi normal.

Berdasarkan hasil perhitungan analisis, dapat diketahui bahwa nilai signifikansi sampel semuanya lebih besar dari 0,05, yaitu 0,068 . Sehingga dapat disimpulkan bahwa data tersebut homogen. 


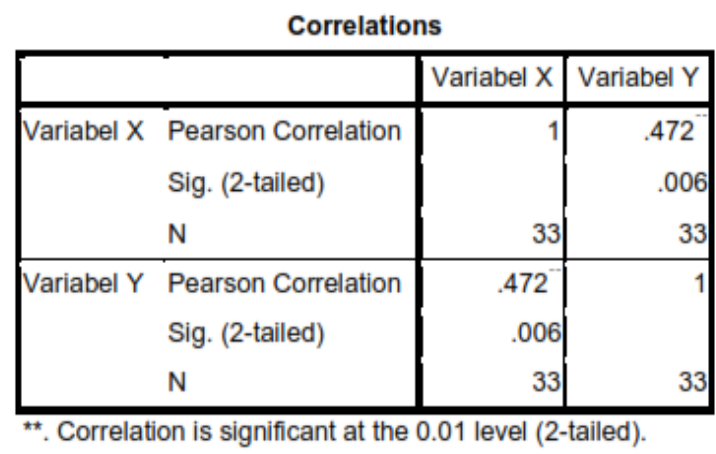

Dari tabel di atas, diperoleh perhitungan koefisien korelasi pearson sebesar 0,472. Berdasarkan taraf signifikan 5\% maka $r=$ 0,339 (dalam tabel rProduct Moment). Oleh karena itu, rhitung > rtabel, maka $\mathrm{Ho}_{\mathrm{o}}$ ditolak dan $\mathrm{Ha}$ diterima. Sehingga dapat disimpulkan berdasarkan tabel interpretasi koefisien. Koefisien determinasi dapat diketahui bahwa :

$\mathrm{KD}=\mathrm{r}^{2} \times 100 \%=(0,472)^{2} \times 100 \%=22,29 \%$.

Berdasarkan hasil perhitungan tersebut, diperoleh nilai koefisien determinasi sebesar 22,29\%. Sehingga dapat disimpulkan bahwa pengaruh variabel bebas (Variabel X) yaitu penggunaan alat peraga AEM (Algebraic Experience Materials) terhadap variabel terikat (Variabel Y) yaitu keterampilan berpikir kreatif sebesar 22,29\% dan sisanya $77,71 \%$ ditentukan oleh faktor lain yang tidak diteliti.

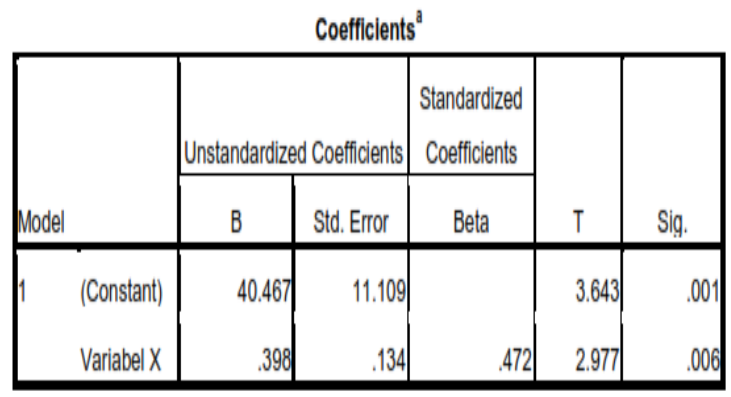

a. Dependent Variable: VariabelY

Pada tabel tesebut menunjukkan regresi yang dicari. Nilai sig di atas adalah 0,006 dan 0,006 < 0,05, dengan demikian dapat disimpulkan bahwa nilai pada kolom B adalah signifikan. Artinya, persamaan yang paling tepat untuk kedua variabel tersebut adalah $Y=a+b X=40,467+0,398 X$. Persamaan tersebut mengandung arti nilai arah regresi sebesar 0,398 (bertanda positif), menyatakan bahwa nilai keterampilan berpikir kreatif akan meningkat sebesar 0,398 kali nilai penggunaan alat peraga AEM (Algebraic Experience Materials) dari nilai konstanta

40,467. Dan nilai 40,467 menyatakan bahwa jika tidak ada respon baik terhadap penggunaan alat peraga AEM (Algebraic
Experience Materials), maka keterampilan berpikir kreatif siswa pada pokok bahasan operasi bentuk aljabar adalah sebesar 40,467.

Dari tabel diatas diekathui thitung sebesar 2,977 dan ttabel diperoleh sebesar 2,042. Karena thitung lebih besar dari ttabel atau 2,977> 2,042 maka H0 ditolak yang artinya terdapat pengaruh variabel independen terhadap variabel dependen.

Untuk menjawab pertanyaan peneliti yang pertama yaitu bagaimana respon siswa ketika dalam pembelajaran matematika operasi bentuk aljabar menggunakan alat peraga AEM (Algebraic Experience Materials), dapat dilihat dari hasil analisis deskriptif angket . Berdasarkan perhitungan setiap indikatornya diperoleh nilai interpretasi rata-rata angket respon siswa terhadap penggunaan alat peraga AEM (Algebraic Experience Materials) pada pokok bahasan operasi bentuk alajabr sebesar $82,23 \%$. Nilai tersebut termasuk kategori sangat kuat, hal ini berdasarkan pada tabel 3.13 pada bab sebelumnya. Peran alat peraga AEM (Algebraic Eksperience Materials) dalam embelajaran matematika sangat kuat, karena dengan alat peraga AEM (Algebraic Eksperience Materials) dapat memberikan siswa pengalaman yang nyata dan akan memberikan motivasi yang lebih kuat. Alat peraga AEM (Algebraic Eksperience Materials) juga memperjelas penyampaian materi aljabar karena dapat menggambarkan unsur-unsur aljabar yang abstrak menjadi konkrit, hal ini ditunjukkan oleh item angket nomor 7. Selain itu, alat peraga AEM (Algebraic Eksperience Materials) dalam pembelajaran matematika lebih menarik karena ditampilkan dengan warna AEM-AEM yang cerah, hal ini ditunjukkan dalam pernyataan angket nomor 1. Siswa merasa senang karena mereka dapat melihat langsung unsur-unsur aljabar yang digambarkan dengan alat peraga AEM (Algebraic Eksperience Materials). Selain itu, siswa merasa senang karena mereka juga dapat menghitung operasi bentuk aljabar dengan cara yang berbeda. Oleh karena itu mereka tertarik pada penggunaan alat peraga AEM (Algebraic Eksperience Materials) dalam pembelajaran matematika pokok bahasan operasi bentuk aljabar. Minat siswa terhadap penggunaan alat peraga AEM (Algebr aic Eksperience Materials) dalam pembelajaran matematika sangat kuat, karena mereka merasa tidak bosan belajar matematika menggunakan AEM (Algebraic 
Eksperience Materials). Selain itu, pada pernyataan angket nomor 15, sebagian besar dari siswa tidak setuju jika penggunaan AEM (Algebraic Eksperience Materials) tersebut membuat mereka kesulitan menghitung operasi bentuk aljabar. Dengan kata lain, mereka merasa terbantu dan tidak merasa kesulitan menyelesaikan operasi bentuk aljabar dengan menggunakan alat peraga AEM (Algebraic Eksperience Materials) karena mereka mengerti cara menggunakannya. Sebagian besar siswa juga sangat setuju bahwa penggunaan AEM (Algebraic

Eksperience Materials) dalam pembelajaran matematika membuat mereka fokus sehingga meningkatkan kreativitas berpikirnya dalam memecahkan masalah operasi bentuk aljabar, hal ini sesuai dengan pernyataan angket nomor 10. Selain itu, siswa juga tertarik untuk mencari banyak cara dalam menyelesaikan operasi bentuk aljabar. Pada umumnya siswa merespon setuju bahwa alat peraga AEM (Algebraic Eksperience Materials) mudah digunakan dan tidak menyita banyak waktu. Selain itu, biaya untuk membuat alat peraga AEM (Algebraic Eksperience Materials) sangat sederhana dan terjangkau, sehingga siswa tertarik untuk mencoba membuatnya di rumah. Siswa juga mengerti cara menggunakan alat peraga AEM (Algebraic Eksperience Materials) dengan baik karena guru menyampaikannya dengan jelas.

Untuk menjawab pertanyaan peneliti yang kedua yaitu bagaimana keterampilan berpikir kreatif siswa ketika dalam pembelajaran operasi bentuk aljabar menggunakan alat peraga AEM (Algebraic Experience Materials), dapat dilihat dari hasil analisis deskriptif tes. Berdasarkan perhitungan setiap indikatornya, diperoleh nilai interpretasi rata-rata tes sebesar $75,21 \%$. Berdasarkan tabel 3.15 nilai tersebut tergolong dalam kategori kuat. Sebagian besar siswa sudah mampu memberikan jawaban yang bervariasi untuk setiap soal, siswa mampu menjawab setiap soal dengan tepat tetapi tidak terpaku pada satu cara, siswa mampu memberikan jawaban menurut pandangannya sendiri, dan siswa mampu mengembangkan atau memperkaya gagasan jawaban suatu soal.

Sedangkan untuk menjawab pertanyaan ketiga yaitu apakah ada pengaruh penggunaan alat peraga AEM (Algebraic Experience Materials) dalam pembelajaran matematika pokok bahasan operasi bentuk aljabar, dapat dilihat dari analisis uji hipotesis. Berdasarkan hasil perhitungan uji regresi linear diperoleh signifikansinya 0,006, nilai tersebut kurang dari 0,05. Artinya model regresi linear dapat digunakan untuk memprediksi keterampilan berpikir kreatif siswa dalam menyelesaikan soal-soal operasi bentuk aljabar. Perhitungan uji regresi sederhana diperoleh persamaan regresi yaitu $Y=a+b X=40,467+0,398 X$. Persamaan tersebut mengandung arti nilai arah regresi sebesar 0,398 (bertanda positif), menyatakan bahwa nilai keterampilan berpikir kreatif akan meningkat sebesar 0,398 kali nilai penggunaan alat peraga AEM (Algebraic Experience Materials) dari nilai konstanta 40,467. Dan nilai 40,467 menyatakan bahwa jika tidak ada respon baik terhadap penggunaan alat peraga AEM (Algebraic Experience Materials), maka keterampilan berpikir kreatif siswa pada pokok bahasan operasi bentuk aljabar adalah sebesar 40,467. Sedangkan perhitungan uji t menunjukkan thitung $>$ ttabel $=2,977>$ 2,042 maka dapat disimpulkan bahwa terdapat hubungan yang signifikan antara penggunaan alat peraga AEM (Algebraic Experience Materials) dengan keterampilan berpikir kreatif. Sedangkan hasil perhitungan uji korelasi menunjukkan adanya pengaruh yang positif yaitu sebesar 0,472 . Berdasarkan tabel 3.16 koefisien korelasi tersebut tergolong kategori cukup kuat. Besarnya pengaruh penggunaan alat peraga AEM (Algebraic Experience Materials) terhadap berpikir kreatif siswa sebesar $22,29 \%$, nilai tersebut dapat dilihat dari perhitungan nilai koefisien determinasi. Dengan demikian, hasil penelitian di kelas VIII C MTs Al-Hidayah Ciawijapura Kecamatan Susukanlebak Kabupaten Cirebon dapat disimpulkan bahwa adanya pengaruh yang positif antara penggunaan alat peraga AEM (Algebraic Experience Materials) terhadap keterampilan berpikir kreatif siswa pada pokok bahasan operasi bentuk aljabar sebesar $22,29 \%$ dan sisanya $77,71 \%$ dipengaruhi oleh faktor-faktor lain yang tidak diteliti. Oleh karena itu, penggunaan alat peraga dalam pembelajaran matematika sangat perlu, karena dengan alat peraga siswa akan lebih tertarik dan lebih besar minatnya dalam matematika, hal ini sejalan dengan pendapat Ruseffendi di dikatakan bahwa anak-anak akan lebih besar minatnya dalam matematika bila pelajaran itu disajikan dengan baik dan menarik, dengan digunakan alat peraga maka anak-anak akan lebih tertarik dalam matematika. Selain itu, Robert mengatakan 
bahwa berpikir merupakan proses mental melalui membayangkan, memanipulasi dan menggambarkan idea abstrak berupa anggapan, pendapat, tanggapan terhadap sesuatu dalam pikiran (mind) seseorang. Menurut teori kognitif bahwa untuk membantu anak mencapai berpikir abstrak harus banyak diberikan pengalamanpengalaman anak, harus dilakukan dengan berbagai alat peragaan.

\section{KESIMPULAN}

1. Respon siswa terhadap penggunaan alat peraga AEM (Algebraic Experience Materials) pada pokok bahasan operasi bentuk aljabar sangat kuat, Siswa erespon baik terhadap penggunaan alat peraga AEM (Algebraic Experience Materials). Hal itu ditunjukkan dari ratarata persentase Angket setiap indikatornya Sebesar 82,23\%.

2. Keterampilan berpikir kreatif siswa dilihat dari persentase rata-rata tes setiap indikatornya sebesar 75,21\% tergolong kategori kuat, ketika dalam pembelajaran operasi bentuk aljabar menggunakan alat peraga AEM (Algebraic Experience Materials).

3. Hasil penelitian menunjukkan bahwa terdapat hubungan yang signifikan antara penggunaan alat peraga AEM (Algebraic Experience Materials) terhadap keterampilan berpikir kreatif siswa kelas VIII MTs. Al-Hidayah Ciawijapura pokok bahasan operasi bentuk aljabar. Hal ini ditunjukkan dengan persamaan regresi $Y=a+b X=$ $40,467+0,398 X$, persamaan tersebut mengandung arti bahwa jika tidak ada respon baik terhadap penggunaan alat peraga AEM (Algebraic Experience Materials), maka keterampilan berpikir kreatif siswa pada pokok bahasan operasi bentuk aljabar adalah sebesar 40,467. Dan nilai arah regresi sebesar 0,398 (bertanda positif), menyatakan bahwa nilai keterampilan berpikir kreatif akan meningkat sebesar 0,398 kali nilai penggunaan alat peraga AEM (Algebraic Experience Materials) dari nilai konstanta 40,467. Hasil perhitungan uji t enunjukkan bahwa thitung $>$ ttabel $=2,977>2,042$ maka dapat disimpulkan bahwa terdapat hubungan yang signifikan antara menggunaan alat peraga AEM (Algebraic Experience Materials) dengan keterampilan berpikir kreatif.

\section{SARAN}

Alat peraga AEM (Algebraic Experience Materials) merupakan salah satu alat peraga matematika yang dapat membantu siswa dalam memahami konsepkonsep aljabar. Selain itu penggunaan Alat peraga AEM (Algebraic Experience Materials) membuat siswa juga merasa senang dan tidak jenuh ketika dalam pembelajaran operasi bentuk aljabar menggunakan alat peraga AEM (Algebraic Experience Materials). Jika siswa dapat memahami konsep-konsep aljabar yang abstrak dengan baik, maka keterampilan berpikir mereka juga akan meningkat. Oleh sebab itu, guru dapat menerapkan alat peraga AEM (Algebraic Experience Materials) dalam pembelajaran matematika pokok bahasan operasi bentuk aljabar untuk meningkatkan keterampilan berpikir kreatif siswa.

Penelitian yang dilakukan penulis ini terbatas pada materi matematika pokok bahasan operasi bentuk aljabar yaitu penjumlahan, pengurangan, perkalian suku satu dengan suku dua dan perkalian suku dua dengan suku dua. Variabel $\mathrm{X}$ yaitu penggunaan alat peraga AEM (Algebraic Experience Materials), sedangkan variabel $\mathrm{Y}$ yaitu terhadap keterampilan berpikir kreatif siswa. Sasaran dalam penelitian ini hanya pada kelas VIII C MTs. Al-Hidayah Ciawijapura. Oleh karena itu, untuk peneliti lainnya diharapkan mampu memperluas permasalahannya, misalnya dapat diterapkan pada materi matematika pada pokok bahasan yang sama, tetapi ditambah dengan koefisien pecahan, diterapkan pada materi matematika pada pokok bahasan yang berbeda, diterapkan di jenjang yang lebih tinggi, atau sampel yang lebih luas.

\section{DAFTAR PUSTAKA}

Arikunto, Suharsimi. 2007. Prosedur Penelitian Suatu Pendekatan Praktik. Jakarta : Rineka Cipta.

Arikunto, Suharsimi. 2009. Dasar-dasar Evaluasi Pendidikan. Jakarta: Bumi Aksara.

Arsyad, Azhar. 1996. Media Pembelajaran. Jakarta: Raja Grafindo Persada.

di unduh Kamis 06 Februari 2014 pukul 14.32.

Ghalia Indonesia.

Hamalik, Oemar. 2001. Proses Belajar Mengajar. Bandung: Bumi Aksara.

Membara, Teguh. 2012. Alat peraga Algebraic Experience Materials $(A E M)$ diakses dalam 
http://teguhbharha.blogspot.com/201

2/01/alat-peraga-

algebraicexperience.html

Mustaqim. 2010. Pengaruh Respon Siswa atas Penggunaan Alat Peraga Papan Geometri dalam Pembelajaran Matematika terhadap Kemampuan Berpikir Kreatifnya pada Pokok Bahasan Geometri Bidang Datar di Kelas VII MTs An-Nur Kota Cirebon. Cirebon: Fakultas Tarbiyah IAIN Syekh Nurjati Cirebon.

Nasehuddin, Toto Syatori. 2011. Metodologi Penelitian. Cirebon: Nurjati Press.

Nurhayati, Eti. 2010. Bimbingan Keterampilan \& Kemandirian Belajar. Bandung: Batic Press.

Pujiati. 2004. Penggunaan Alat Peraga dalam Pembelajaran Matematika SMP. PPPG Matematika: Yogyakarta.

Riduwan. 2012. Belajar Mudah Penelitian untuk Guru Karyawan dan Peneliti Pemula. Bandung: Alfabeta.

Siregar Eveline dan Hartini Nara. 2010. Teori Belajar dan Pembelajaran. Bogor:

Sudjana, Nana.1987. Dasar Dasar Proses Belajar Mengajar. Bandung: Sinar Baru Adgensindo .

Surya, Mohamad. 2004. Psikologi Pembelajaran dan Pengajaran. Bandung: Pustaka Bani Quraisy. 